\title{
Healthcare Costs and Resource Use of Patients with Dupuytren Contracture Treated with Collagenase Clostridium Histolyticum or Fasciectomy: A Propensity Matching Analysis [Corrigendum]
}

\author{
Zah V, Pelivanovic J, Tatovic S, et al. Clinicoecon \\ Outcomes Res. 2020;12:635-643.
}

The authors have advised that the Disclosure statement on page 642 is incorrect. The first sentence "Vladimir Zah, Djurdja Vukicevic, and Martina Imro are employees of ZRx Outcomes Research Inc. (institution founded by Endo Pharmaceuticals to conduct the present analysis), and have received grants from Endo Pharmaceuticals Inc" should read "Vladimir Zah, Djurdja Vukicevic, and Martina Imro are employees of ZRx Outcomes Research Inc. (institution funded by Endo Pharmaceuticals to conduct the present analysis), and have received grants from Endo Pharmaceuticals Inc".

The authors apologize for this error.

\section{Publish your work in this journal}

ClinicoEconomics and Outcomes Research is an international, peerreviewed open-access journal focusing on Health Technology Assessment, Pharmacoeconomics and Outcomes Research in the areas of diagnosis, medical devices, and clinical, surgical and pharmacologica intervention. The economic impact of health policy and health systems organization also constitute important areas of coverage. The manuscript management system is completely online and includes a very quick and fair peer-review system, which is all easy to use. Visit http://www.dovepress.com/testimonials.php to read real quotes from published authors. 